\title{
THE APPLICATION OF FRACTURE MEGHANICS TO THE PROBLEM OF CREVASSE PENETRATION
}

\author{
By R. A. Sмiтн \\ (Department of Engineering, University of Cambridge, Cambridge $\mathrm{CB}_{3}{ }_{\mathrm{I}} \mathrm{PZ}$, England)
}

\begin{abstract}
The elastic stress intensity factor is a parameter used in fracture mechanics to describe stress conditions in the vicinity of the tip of a sharp crack. By superimposing solutions of stress intensity factors for different loading conditions, equations are derived which model crevasses in ice. Solutions are presented for the theoretical depth of isolated crevasses, free from or partially filled with water. Close agreement exists with a previous calculation by Weertman using a different technique. The effect of crevasse spacing is investigated and it is demonstrated that closer spacing always reduces crevasse depth, but over a wide range of spacing the predicted variation in depth is slight.

RÉsumé. L'application de la mecanique des fractures au probleme de la pénétration des crevasses. Le facteur d'intensité de l'effort élastique est un paramètre utilisé en mécanique des fractures pour décrire les conditions des contraintes au voisinage de l'extrémité d'une fracture étroite. En superposant les solutions donnant les facteurs d'intensité d'effort pour différentes conditions de charge, on a établi des équations qui simulent les crevasses dans la glace. On présente des solutions pour la profondeur théorique de crevasses isolées libres, ou partiellement remplies d'eau. On est en très bon accord avec des calculs anciens menés par Weertman par des méthodes différentes. On a cherché à déterminer l'effet de l'espacement entre les crevasses et on a démontré que la réduction de cet espacement réduit toujours la profondeur des crevasses, mais pour une large gamme d'espacements, la variation de profondeur attendue est faible.

Zusammenfassung. Die Anwendung der Bruch-Mechanik auf das Problem der Spaltentiefe. In der BruchMechanik wird der Intensitätsfaktor der elastischen Spannung als Parameter zur Beschreibung der Spannungsverhältnisse in der Umgebung der Kante einer scharfen Spalte benutzt. Durch Úberlagerung von Lösungen der Spannungsintensitätsfaktoren für verschiedene Lastfälle werden Gleichungen hergeleitet, die Spalten in Eis beschreiben. Mitgeteilt werden die Lösungen für die theoretische Tiefe isolierter Spalten, die entweder wasserfrei oder teilweise wassergefüllt sind. Zu einer früheren Berechnung von Weertman, die auf einer anderen Methode beruht, besteht gute Übereinstimmung. Die Auswirkung der Scharung von Spalten wird untersucht, wobei sich zeigt, dass engere Scharung stets die Spaltentiefe verringert, dass aber über einen weiten Scharungsbereich die vorberechnete Tiefenänderung nur gering ist.
\end{abstract}

\section{Symbols}

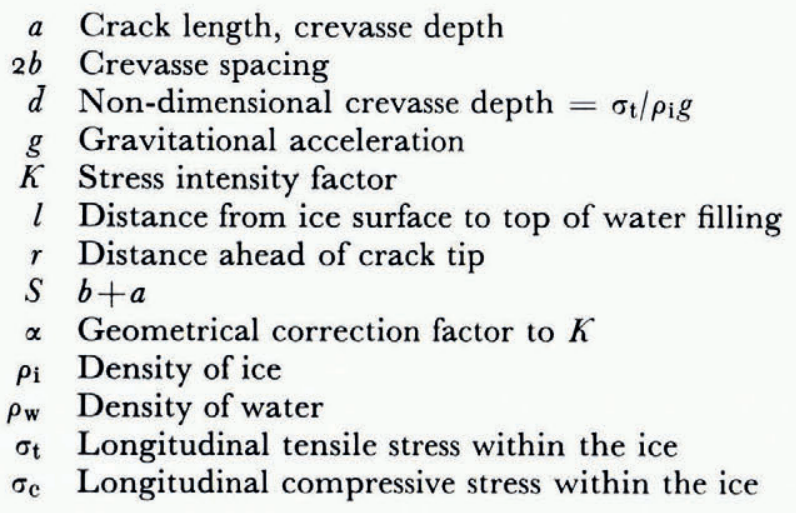

\section{INTRODUCTION}

Very few quantitative calculations of the penetration depth of a crevasse into a glacier have been made. Nye (1955), who equated the overburden pressure to the tensile stress, estimated the depth of penetration to be $\sigma_{t} / \rho_{\mathrm{i}} g$, for closely spaced, water-free crevasses, where $\sigma_{\mathrm{t}}$ is the tensile stress within the glacier causing extending flow, $\rho_{\mathrm{i}}$ is the density of ice and $g$ is the acceleration due to gravity. Weertman (1973) calculated the depth of an isolated crevasse by using a distribution of infinitesimal edge dislocations as a model for the opened 
crevasse. He found the depth of an isolated crevasse to be a factor of $\pi / 2$ greater than the Nye depth, and also showed that the presence of water in a crevasse can increase its depth and that a crevasse filled with water to at least $97.4 \%$ of its depth can penetrate to the bottom of a glacier. A recent exchange of correspondence (Robin, 1974; Weertman, 1974) concerning the effects of both spacing and water filling on crevasse depths has prompted the present author to apply the concepts of fracture mechanics to this problem.

\section{DEFINITION OF STRESS INTENSITY FACTOR}

The basis of fracture mechanics lies in the stress analysis of a sharp crack in an infinite body. Irwin (1957) introduced the concept of the stress intensity factor to describe the magnitude of the local stress-strain field in the vicinity of the crack tip. He recognized that the field near to the crack tip always had the same geometrical distribution, the magnitude being controlled by the crack length, the applied stress, the geometry of the loaded body, and the orientation of the crack within the body. In general, the stress intensity factor $K$ is defined as

$$
K=\alpha \sigma \sqrt{ } a
$$

where $\sigma$ is the remote applied stress, $a$ the crack length and $\alpha$ a geometrical correction factor. Once the stress intensity factor for a particular configuration is known, then the stress field in the vicinity of the crack tip can be examined by substituting it into the general solution for an infinite body. For the case of an opening tensile stress in the plane of the crack across the crack tip, the required expression is

$$
\sigma=K / \sqrt{ }(2 r)
$$

where $r$ is the distance ahead of the crack tip. It should be noted at this stage that an infinite stress is predicted by a singularity at $r=0$, the position of the crack tip. For the purpose of this discussion, the fracture criterion which is assumed is that ice cannot sustain a large tensile stress. Thus, the crevasse will adjust its depth to reduce the stress intensity factor, and hence the crack tip stresses, to zero. A negative stress intensity factor has no meaning other than that the crack faces are held closed.

One difficulty in this fracture-mechanics approach with its assumption of linear elasticity has been that, for its application to realistic geometries, accurate stress analyses are needed in order to calculate the geometrical term $\alpha$ in Equation ( 1 ). The solutions required for an investigation of the problems of spacing and water filling of crevasses have recently become available.

\section{STRESSES AGTiNG ON A TYPICAL ISOLATED GREVASSE}

Figure I illustrates the loadings applied to an isolated crevasse. The longitudinal tensile stress in the glacier, assumed constant throughout the depth, can be modelled as a uniform stress acting on an edge crack in an infinite half-plane. Both the stresses due to the pressure of water and the overburden ice pressure vary linearly with depth. The stress analysis for this problem has been given by Hartranft and Sih (1973). By a superposition of these load cases, the stress intensity factor for a crevasse of depth $a$, filled with water to a depth $l$ from the surface is given by

$$
K=\mathrm{I} . \mathrm{I} 2 \sigma_{\mathrm{t}} \sqrt{ } a+0.683 \rho_{\mathrm{w}} g(a-l)^{\frac{3}{2}}-0.68_{3} \rho_{\mathrm{i}} g a^{\frac{3}{2}}
$$

where the water-filling term is approximated by neglecting the depth of the crevasse above the water level.

Several special cases can now be considered: 
THEORY OF CREVASSE PENETRATION

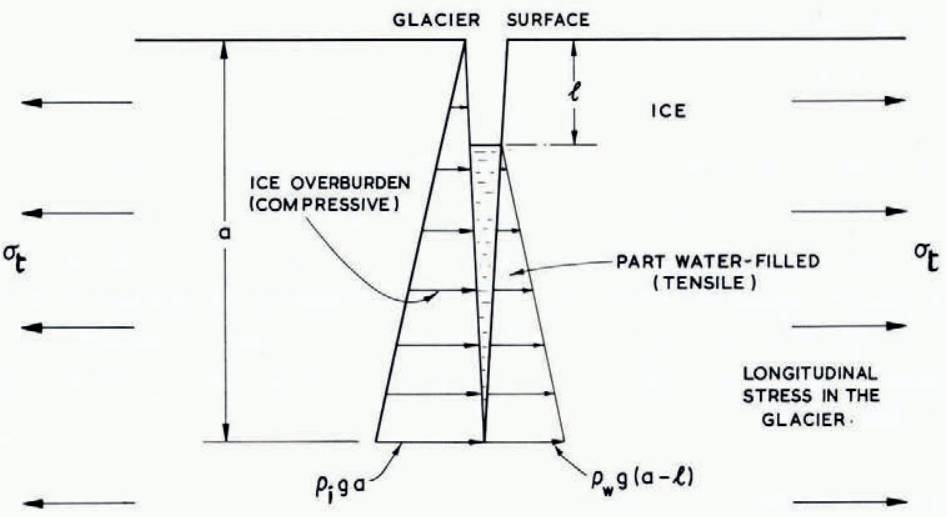

Fig. 1. Idealized tresses acting on an isolated crecasse.

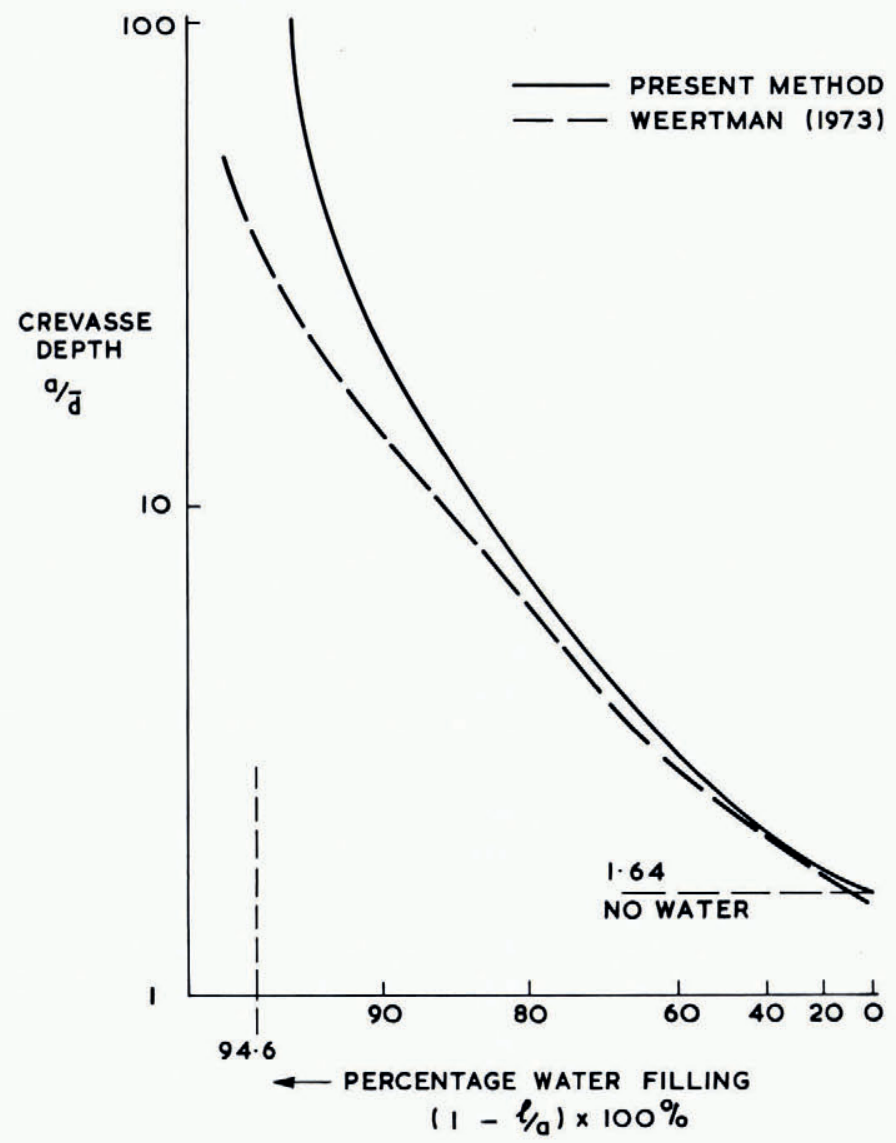

Fig. 2. Crevasse depth plotted against the depth of water filling (as a percentage of depth). 
Case I. No water in the crevasse

On putting $l=a$, Equation (3) becomes

$$
K=\mathrm{I} .12 \sigma_{\mathrm{t}} \sqrt{ } a-0.683 \rho_{\mathrm{i}} g a^{3} .
$$

Hence the crevasse depth required to relieve the crack tip stresses becomes $(K=0)$

$$
a=\mathrm{I} .64 \sigma_{\mathrm{t}} / \rho_{\mathrm{i}} g=\mathrm{I} .64 \bar{d} \text {. }
$$

This is in excellent agreement with Weertman's result of $\pi d / 2(=\mathrm{I} .57 d)$ where $d=\sigma_{\mathrm{t}} / \rho_{\mathrm{i}} g$, the Nye value for closely spaced crevasses. It is interesting to substitute typical numerical values into Equation (4). For $\rho_{\mathrm{i}}=0.92 \times \mathrm{IO}^{3} \mathrm{~kg} \mathrm{~m}^{-3}, g=9.8 \mathrm{I} \mathrm{m} \mathrm{s}^{-2}$ and $\sigma_{\mathrm{t}}=2 \times \mathrm{IO}^{5} \mathrm{~N} \mathrm{~m}^{-2}$, then $a$ is approximately $36 \mathrm{~m}$, a realistic value in that crevasses have seldom been observed to be deeper than this.

Case II. Crevasse partially filled with water

Equation (3) can be equated to zero to yield

$$
\mathrm{I} . \mathrm{I} 2 \sigma_{\mathrm{t}} \sqrt{ } a=0.683 g \rho_{\mathrm{i}}\left[a^{\frac{3}{2}}-\frac{\rho_{\mathrm{w}}}{\rho_{\mathrm{i}}}(a-l)^{\frac{3}{2}}\right] .
$$

Rearranging and putting $\rho_{\mathrm{w}} / \rho_{\mathrm{i}}=\mathrm{I} .087$,

$$
a=\frac{\mathrm{1} .639 d}{\left\{\mathrm{I}-\mathrm{1} .087\left[\frac{\mathrm{1}-l}{a}\right]^{\frac{3}{3}}\right\}} .
$$

Equation (5) can now be evaluated for various levels of water in the crevasse, i.e. different values of $l / a$. The results are plotted in Figure 2 which represents the deepest crevasse that can exist for given values of longitudinal stress and depth of water filling. It can be seen that any crevasse filled with water to a level which is equal to or greater than $94.6 \%$ of its depth can penetrate to the bottom of the glacier. The dotted line shows results from the analysis due to Weertman. The results are very similar.

\section{Stresses acting on A SYSTEM OF EQUally SPACED PARALlel GReVASSES}

\section{Case I. Water-free crevasse}

Consider the system of parallel crevasses of depth $a$ and equal separation $2 b$ (Fig. 3 ). The effect of the spacing is to "blunt" the individual stress fields at the crevasse tips. Benthem and Koiter (1973) have computed stress intensity factors for this configuration. These are given by the functions

$$
\kappa=F\left\{\frac{b}{S}\right\} \sqrt{\frac{b}{S}} \sigma \sqrt{ } a,
$$

where

$$
\begin{aligned}
F\left\{\frac{b}{S}\right\}=\frac{\mathrm{I}}{\sqrt{ } \pi}\left[\mathrm{I}+\frac{\mathrm{I}}{2}\left(\frac{b}{S}\right)+\right. & \left.\frac{3}{8}\left(\frac{b}{S}\right)^{2}+\frac{5}{\mathrm{I} 6}\left(\frac{b}{S}\right)^{3}+\frac{35}{\mathrm{I} 28}\left(\frac{b}{S}\right)^{4}+\frac{63}{25^{6}}\left(\frac{b}{S}\right)^{5}+\frac{23 \mathrm{I}}{\mathrm{IO24}}\left(\frac{b}{S}\right)^{6}\right]+ \\
& +22.50 \mathrm{I}\left(\frac{b}{S}\right)^{7}-63.502\left(\frac{b}{S}\right)^{8}+58.045\left(\frac{b}{S}\right)^{9}-\mathrm{I} 7.577\left(\frac{b}{S}\right)^{10}
\end{aligned}
$$

and

$$
S=b+a \text {. }
$$

For water-free crevasses, the compressive stresses applied to each crevasse (due to the ice overburden) are unaffected by spacing, although the strength of the crack tip singularity 


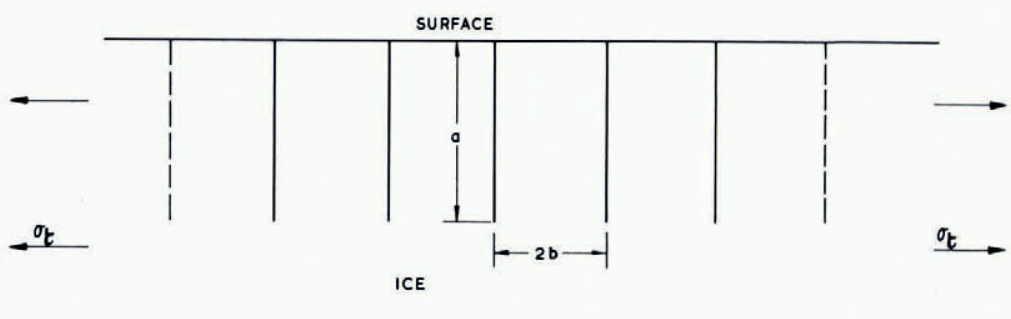

Fig. 3. System of equally spaced parallel crevasses.

might be expected to increase as the spacing becomes much less than the depth. Neglecting this increase (supposed small) with decreasing spacing, the total stress intensity factor for the sum of the longitudinal stress and the compressive ice stresses can be written as

$$
K=F\left\{\frac{b}{S}\right\} \sqrt{\frac{b}{S}} \sigma \sqrt{ } a-0.683 \rho_{\mathrm{i}} g(a)^{\frac{3}{2}} .
$$

When $b \gg a$, i.e. an isolated crevasse, then $b / S$ tends to I and $F\left\{\frac{b}{S}\right\} \sqrt{\frac{b}{S}}$ tends to I.I2, and Equation (7) reduces to the previous solution, Equation (4). For other finite values of $b / S$, Equation (7) was equated to zero and solved using a computer program written to evaluate Equation (6). The results are shown in Figure 4. For a crevasse depth equal to that calculated by Nye $(d=\mathrm{I}$, typically $22 \mathrm{~m}$ in depth) the expected separation is about $2.7 \times 22 \mathrm{~m}$, approximately $60 \mathrm{~m}$, somewhat greater than his closely spaced approximation might suggest. The results of Figure 4 serve to illustrate the insensitivity of depth to spacing. Again, based on a value of $d=22 \mathrm{~m}$, the depth of crevasses spaced only I $\mathrm{m}$ apart is reduced to $5.5 \mathrm{~m}$ compared with a depth of $36 \mathrm{~m}$ at infinite separation. In practical terms, although the depth is always reduced by closer spacing, the depth of the closest-spaced crevasses likely to occur in practice still presents a danger to falling bodies! Unfortunately, a search of the literature has yielded no experimental observations for comparison with Figure 4 .

\section{Case II. Water-filled crevasses in compressive longitudinal stress fields}

Now consider the case of a crevasse which has been opened by a tensile stress field, filled with water, and moved into a region of compressive stress, such as would exist at the base of a concave slope, for example, an ice-fall. Equation (3) becomes

$$
K=0.683 g a^{\frac{3}{2}}\left(\rho_{\mathrm{w}}-\rho_{\mathrm{i}}\right)-\mathrm{I} .12 \sigma_{\mathrm{c}} \sqrt{ } a .
$$

The criterion $K>0$ gives an expression for the minimum depth that the crevasse must attain before further growth can take place, viz.

$$
a=\frac{\mathrm{I} .64 \sigma_{\mathrm{c}}}{\left(\rho_{\mathrm{w}}-\rho_{\mathrm{i}}\right) g} .
$$

If the crevasse is already deeper than this critical depth, extension to the bedrock at the base of the glacier will continue. Weertman (1973) has discussed the problem posed by the absence, in practice, of crevasses which penetrate to the glacier bottom. He suggests that water-filled crevasses which do reach the bottom surface are pinched closed at a shallow depth. The present analysis supports this view. When the crevasse has opened up in a tensile stress field, filled with water, and moved into a region of compressive stress, then a negative stressintensity factor exists for that part of the crevasse lying between the surface of the glacier and a depth of $\mathrm{I} .64 \sigma_{\mathrm{c}} /\left(\rho_{\mathrm{w}}-\rho_{\mathrm{i}}\right) g$. The faces of the crevasse are held together over this depth interval. 


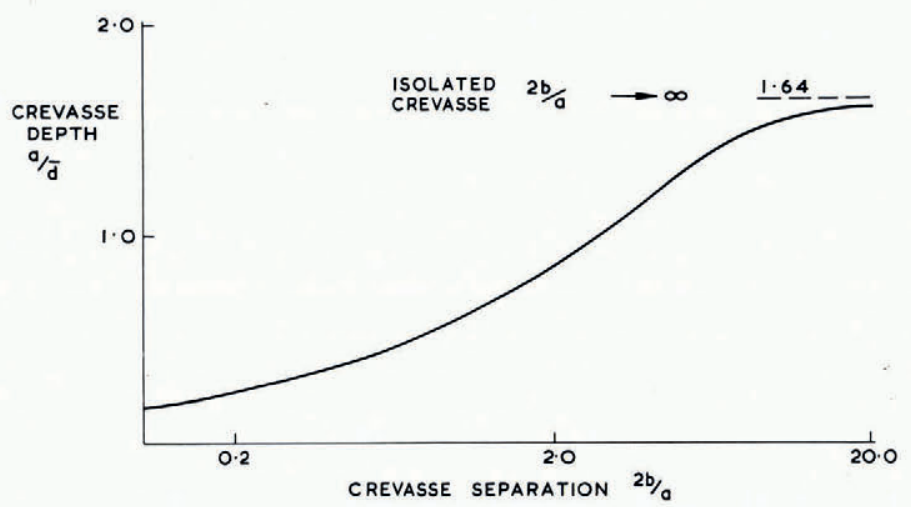

Fig. 4. Crevasse depth plotted against the crevasse separation. The crevasses are assumed to be water-free.

\section{Conalusions}

I. The use of the concept of the elastic stress intensity factor from fracture mechanics has enabled the depth of an isolated crevasse in ice to be calculated as $1.64 \bar{d}$, compared with a previous value of $1.57 d$ (Weertman, I 973), where $d=\sigma_{\mathrm{t}} / \rho_{\mathrm{i}} g$.

2. The depth of the crevasse has been shown to increase with increasing depth of water filling. Any crevasse filled with water to a level equal to or greater than $94.6 \%$ of its depth can penetrate to the bottom of the glacier; Weertman's calculations yielded a similar value of $97.4 \%$. The lack of such crevasses in practice may be tentatively explained as due to the presence of compressive longitudinal stress in the glacier which causes the top of the crevasse to close.

3. A reduction in the spacing of a system of parallel crevasses is shown to reduce crevasse depth, but over a wide range of spacing the effect is small, typically, the infinite-spacing depth of $36 \mathrm{~m}$ is reduced to a depth of $5.5 \mathrm{~m}$ for crevasses only $\mathrm{I} \mathrm{m}$ apart.

4. By using concepts of fracture mechanics, useful results for some simple crevasse problems have been produced relatively easily. An extension of these methods to more complex situations should prove worthwhile, in particular, the solution of these problems might be attempted for a more realistic variation of longitudinal stress with depth.

MS. received 3 September 1975 and in revised form ${ }_{13}$ October 1975

\section{REFERENCES}

Benthem, J. P., and Koiter, W. T. 1973. Asymptotic approximations to crack problems. (In Sih, G. C., ed. Methods of analysis and solution of crack problems. Groningen, Noordhoff, p. 131-78.)

Hartranft, R. J., and Sih, G. C. 1973. Alternating method applied to edge and surface crack problems. (In Sih, G. C., ed. Methods of analysis and solution of crack problems. Groningen, Noordhoff, p. 179-238.)

Irwin, G. R. 1957. Analysis of stresses and strains near the end of a crack traversing a plate. Journal of Applied Mechanics, Vol. 24, No. 3, p. 361-64.

Nye, J. F. 1955. Comments on Dr. Loewe's letter and notes on crevasses. Journal of Glaciology, Vol. 2, No. I7, p. 512-14.

Robin, G. de Q. 1974. Depth of water-filled crevasses that are closely spaced. Fournal of Glaciology, Vol. 13, No. 69 , p. 543 .

Weertman, J. 1973. Can a water-filled crevasse reach the bottom surface of a glacier? Union Géodésique et Géophysique Internationale. Association Internationale d'Hydrologie Scientifique. Commission de Neiges et Glaces. Symposium on the Hydrology of Glaciers, Cambridge, 7-13 September 1969, p. 139-45.

Weertman, J. 1974. Depth of water-filled crevasses that are closely spaced. fournal of Glaciology, Vol. I3, No. 69, p. 544 . 